\title{
Internetfüggöség, alvászavar, depresszió és életminőség összefüggésének vizsgálata a bajai kórház dolgozóinak körében
}

\author{
Internet addiction, sleep disturbance, \\ depression and quality of life among healthcare workers
}

Tóth Gábor ${ }^{1,2}$, Tibold Antal ${ }^{1}$, Fejes Éva ${ }^{3}$, Kapus Krisztián ${ }^{1}$, Fehér Gergely ${ }^{1}$

${ }^{1}$ Pécsi Tudományegyetem, Általános Orvostudományi Kar, Klinikai Központ, Foglalkozás egészségügyi és Munkahigiénés Központ, Pécs, ${ }^{2}$ Szent Rókus Kórház, Baja, ${ }^{3}$ Komlói Egészségcentrum, Bányászati Utókezelő és Éjjeli Szanatórium Egészségügyi Központ, Komló

Az internet széleskörü elterjedése alapjaiban változtatta meg hétköznapjainkat; mind a munka, mind a szabadidős tevékenységek alapvető része lett. Kedvező hatásai mellett árnyoldalai is vannak, többek között a kényszeres, az egész életmódot átalakító, kontrollvesztett internetezés a függöségek között új szindrómának számít. Jelen vizsgálatunk célja az internet addikció, depresszió, alvászavar és életminőség közötti kapcsolat vizsgálata kérdőíves felmérés segítségével a bajai Szent Rókus Kórház dolgozói között. Multivariációs analízis során (demográfiai adatok, rizikótényezők és betegségek figyelembe vételével is) az alvászavar (OR: 1,137, $p=0,022$ ) és a depresszió (OR: $3,949, p<0,001)$ az internetfüggőség független rizikófaktorának bizonyult.

The extensive availability of the internet has dramatically changed our lives as part of both working and private sphere. Despite of its advantages the widespread use has led to the recognition of uncontrolled, problematic internet use, the so-called Internet Addiction Disorder (IAD). The aim of our present study was to analyse the association among internet addiction, sleep disturbance (insomnia), depression and quality of life among healthcare workers employed in Szent Rókus Hospital, Baja. In a multivariate analysis also including demographic factors, risk factors and diseases, insomnia (OR: 1.137, $p=0.022$ ) and depression (OR: $3.949, p<0.001$ ) were also significantly associated with internet addiction.

\section{BEVEZETÉS}

Az internet széleskörű elterjedése alapjaiban változtatta meg hétköznapjainkat; mind a munka, mind a szabadidős tevékenységek alapvető része lett. Kedvező hatásai mellett árnyoldalai is vannak, többek között a kényszeres, az egész életmódot átalakító, kontrollvesztett internetezés a függőségek között új szindrómának számít [1]. Az internetfüggőség felismerésének gátat szab, hogy olyan társadalmilag elfogadott technikai vívmány, amelyet mindannyian használunk a mindennapok során, így nehezen tủnik fel, ha környezetünkben valaki függővé válik, általában sem a beteg, sem a környezet nem ismeri fel a viselkedési problémát [2]. A jelenség létezése sokáig vita tárgya volt, mostanra elfogadottá vált, különösen a 25 év alattiak körében. Ennek ellenére az internetfüggőség kórképként való besorolása nem történt még meg, noha az online játékfüggőség kategóriát már használja a DSM IV beosztás [3,4].

Közelmúltbéli összefoglaló analízisek alapján az internetfüggőség a populáció akár 7-10\%-át érintheti, a 25 év alattiak körében ez akár a $20 \%$-ot is elérheti vagy meg is haladhatja $[1,5]$. Legfontosabb rizikófaktorai közé tartozik az életkor (minél fiatalabb korban használ a gyermek digitális eszközöket, annál nagyobb a függőség kialakulásának veszélye), a férfi nem, az alacsony jövedelem, a nagyvárosi lét, a sekélyes önbecsülés és a társas támogatások hiánya/nem megfelelő volta (család, barátok, iskola munkahely) [6,7]. Az internetfüggőség gyakran szorongással, depresszióval, tiltott szerhasználattal és malnutrícióval társulhat, továbbá iskolai/munkahelyi kiégéshez vezethet $[4,8,9]$. Az előbb felsorolt mentális rendellenességek és internet addikció közötti okokozati kapcsolat nem teljesen tisztázott $[4,8,9,10]$.

$A z$ internetfüggőség döntően fiatalkorúaknál vizsgált jelenség, de felnőtteknél is előfordul, noha az erre vonatkozó irodalmi adatok még messze nem teljesek [10].

Korábban már vizsgáltuk az internetfüggőség előfordulását és rizikófaktorait a bajai Szent Rókus Kórház egészségügyi dolgozói körében [11]. Jelen vizsgálatunk célja az internet addikció, depresszió, alvászavar és életminőség közötti kapcsolat vizsgálata kérdőíves felmérés segítségével.

\section{VIZSGÁLATI ALANYOK ÉS MÓDSZEREK}

A strukturált kérdőívekre alapozott keresztmetszeti vizsgálat 2020. január 1. és augusztus 31. között zajlott a bajai Szent Rókus Kórházban a Regionális Kutatásetikai Bizottság és a Pécsi Tudományegyetem Etikai Bizottságának 8434/PTE/2020. számú engedélye alapján. Beválasztási kritérium volt, hogy a válaszadók az adott intézményeknél a kutatás időpontjában közalkalmazotti, alkalmazotti, megbízási jogviszonyban vagy személyes közreműködőként foglalkoztatottak legyenek. Nem kerültek be a mintába azok a dolgozók, akik tartós távolléten voltak a vizsgálat lebonyolításának időpontjában, mint az korábban közlésre került [11].

A vizsgálat során tekintetbe vett demográfiai adatok az alábbiak voltak: életkor, nem, családi állapot, gyermekek 
száma, iskolai végzettség, munkakör, munkával eltöltött évek száma, munkarend, jogviszony típusa, másodállás vállalása [11]. Az alábbi rizikófaktorokat/betegségeket vettük tekintetbe a vizsgálat során: dohányzás, alkoholfogyasztás, drogfogyasztás, diabétesz, hipertónia, iszkémiás szívbetegség, mozgásszervi fájdalom és depresszió a kórtörténetben [11].

Az internetfüggőség vizsgálata a Demetrovics és mtsai. által kifejlesztett, magyar nyelven is rendelkezésre álló, 30 kérdésből álló Problémás Internethasználat Kérdőív segítségével történt [12]. A személyeknek valamennyi kérdésre vonatkozóan egy 1-től 5-ig terjedő, ötfokú skálán kellett megítélniük, hogy az adott állítás mennyire igaz rájuk egy harminc tételes kérdőívben. 41 pont vagy azt meghaladó érték függőséget jelez korábbi publikációk eredményei alapján [13,14].

A hangulatzavar kimutatásához a Beck-féle depresszió rövidített kérdőívet alkalmaztuk. A skála értékelésekor az ahhoz rendelt pontszámok segítségével elkülöníthetünk súlyos, közepesen súlyos, enyhe depressziót, illetve depresszió nélküli állapotot $[15,16]$.

Az alvászavart az Athén Insomnia Skála (AIS) segítségével mértük fel $[17,18]$. Maga a kérdőív egy nyolc kérdésből álló skála, amelyben öt az éjszakai tüneteket méri fel (elalvási és átalvási nehézség, korai felébredés), három pedig a nappali következményekre kérdez rá. Minél magasabb a pontérték, annál rosszabb az alvásminőség (maximum 24 pont lehetséges). 10 pont esetén már klinikailag szignifikáns insomniát jelez a kérdőív.

Az életminőséget az EQ-5D (health-related quality of life) általános mérésére alkalmas, önkitöltős kérdőív segítségével mértük fel [19]. A kérdőív 5 dimenziót mér (mozgékonyság, önellátás, szokásos napi tevékenységek, fájdalom/rossz közérzet, illetve szorongás/lehangoltság), melyekhez minden esetben egy 3 fokozatú skálának megfelelő kijelentéssor tartozik. Az 5 dimenzió egyes értékeinek összevonásával egy indexbe sűríthetjük az általános egészségi állapotot. A kérdőívet egy ún. EuroQol-skála, vagy más néven egy VAS (Vizuál Analóg Skála) egészíti ki, amely 100 fokozatú és leginkább egy hőmérőre emlékeztet. A válaszadóknak ezen a skálán kell bejelölniük, hogy milyennek tartják egészségi állapotukat. $A$ skála 0 pontja az elképzelhető legrosszabb, míg a 100 az elképzelhető legjobb egészségi állapotot tükrözi [20].

Statisztikai elemzés során az adatok a leíró statisztika eszköztárával, T-próbával, chi-négyzet próbával, varianciaanalízissel, faktoranalízissel történt elemzés SPSS szoftver segítségével (SPSS 15.00, IBM, New York, NY, USA)

\section{EREDMÉNYEK}

Összesen 600 kérdőív került kiküldésre, ebből 485 kitöltött érkezett vissza (válaszadási ráta 80,8\%). 49 szakorvos (10,1\%), 198 nővér (40,9\%), 123 orvosi asszisztens $(25,4 \%)$, 73 egyéb szakdolgozó $(15,1 \%)$ és 42 kiszolgáló személyzethez (takarítás, karbantartás stb.) tartozó dolgozó (1,7\%) töltötte ki kérdőívünket. Adataikat az 1. táblázat tartalmazza.

A Problémás Internethasználat kérdőív alapján a dolgozók 3,9\%-a szenvedett internetfüggőségben (19/485). Az

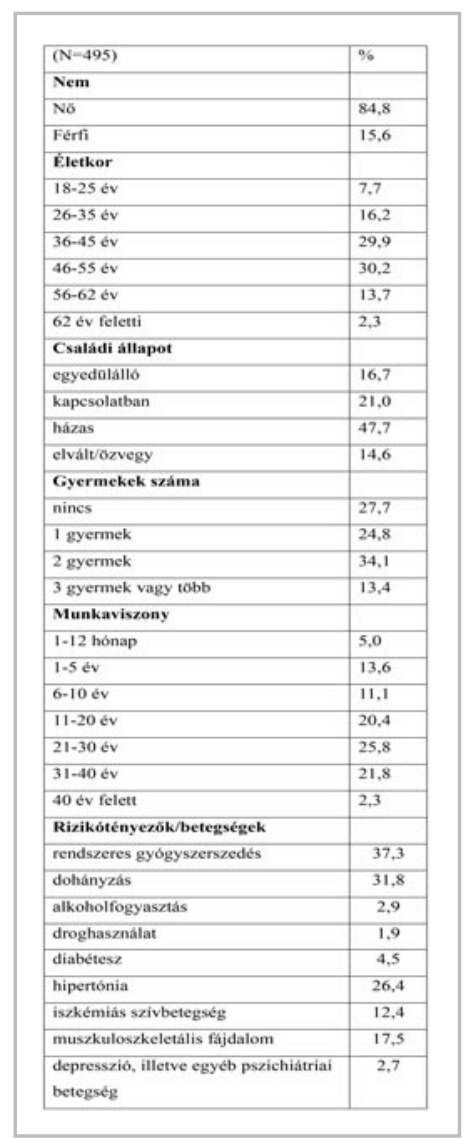

1. táblázat

Demográfiai adatok, rizikófaktorok és kórelözmény a vizsgált populációban

internetfüggőség összefüggése a demográfiai adatokkal és a vizsgált rizikótényezőkkel/betegségekkel már korábban közlésre került, így ennek részletezésétől eltekintettünk [11].

A rövidített Beck Depressziós kérdőív eredményei alapján a dolgozók csupán 33,9\%-a nem szenved hangulatzavarban (164/485), többségük $(64,1 \%, 298 / 485)$ enyhe, 2\%-uk közepes mértékben (23/485) depressziós, súlyos fokú depresszió nem fordult elő a vizsgált dolgozók körében. Az enyhe fokú depresszió előfordulása szignifikánsan magasabb volt az internetfüggők körében (78,9 vs. 60,7\%, p<0,001) (2. táblázat).

A vizsgálatba bevont dolgozók túlnyomó többsége (76,3\%) enyhe fokú alvászavarban (insomniában) szenved, súlyos fokú alvászavar 23,1\%-ban detektálható (112/485). Érdekes módon normális alvásról csupán 0,6\%-uk számolt be (3/485) az Athens Insomnia kérdőív eredményei alapján. Súlyos fokú alvászavar kialakulása szignifikánsan gyakoribb volt az internetfüggők körében (42,1 vs 22,3\%, p<0,05) (2 táblázat).

$A z$ internetfüggőség szignifikánsan rosszabb életminőséggel járt az EQ-5D kérdőív eredményei alapján (82,6 \pm $19,04$ vs. $76,7 \pm 23,51$ pont, $p<0,05)$. Alcsoportelemzés során az önellátás és a fájdalom alcsoportokban mutatkozott különbség, az internetfüggőség alacsonyabb szintű önellátás képességgel járt és gyakoribb volt a fájdalom előfordulása (2. táblázat).

Multivariációs analízis során (fent felsorolt demográfiai adatok, rizikótényezők és betegségek figyelembe vételével is) az alvászavar (OR: 1,137, p=0,022) és a depresszió (OR: 3,949, p<0,001) az internetfüggőség független rizikófaktorá- 


\begin{tabular}{|c|c|c|}
\hline & $\begin{array}{l}\text { nincs internetfüggöség } \\
(\mathrm{n}=466)\end{array}$ & $\begin{array}{l}\text { internetfüggök } \\
(\mathrm{n}=19)\end{array}$ \\
\hline \multicolumn{3}{|l|}{ Depresszió } \\
\hline nincs & $160(34,3 \%)$ & $4(21 \%)$ \\
\hline enyhe & $283(60,7 \%)$ & $15(78,9 \%)^{*}$ \\
\hline közepes & $23(4,9 \%)$ & $0(0,0 \%)$ \\
\hline súlyos & $0(0,0 \%)$ & $0(0,0 \%)$ \\
\hline \multicolumn{3}{|l|}{ Alvászavar } \\
\hline nincs & $3(0,6 \%)$ & $0(0,0 \%)$ \\
\hline enyhe & $358(76,8 \%)$ & $12(57,9 \%)$ \\
\hline súlyos & $104(22,3 \%)$ & $8(42,1 \%)^{*}$ \\
\hline Életminöség (pont) & $82,6 \pm 19,04$ & $76,7 \pm 23,51^{*}$ \\
\hline mozgékonyság & 1,32 & 1,42 \\
\hline Önellátás & 1,03 & $1,38^{*}$ \\
\hline $\begin{array}{l}\text { szokásos napi } \\
\text { tevékenység }\end{array}$ & 1,15 & 1,42 \\
\hline fájdalom/rossz közérzet & 1,44 & 1,79 * \\
\hline szorongás/depresszió & 1,25 & 1,47 \\
\hline
\end{tabular}

\section{2. táblázat}

Internetfüggöség, depresszió, alvászavar és életminöség közötti összefüggés

${ }^{*} p<0,05$

nak bizonyult. Az életminőség kapcsán hasonló összefüggést nem sikerült kimutatnunk

\section{MEGBESZÉLÉS}

A kényszeres, az egész életmódot átalakító, kontrollvesztett internetezés a függőségek között új szindrómának számít. Az internetfüggők egész életmódja átalakul, noha ennek definíciója, orvosi besorolása még vitatott, az tény, hogy az érintettek önként, esetlegesen felszólításra is képtelenek csökkenteni az internethasználatot, ennek hiányában elvonási szindrómákkal megegyező tüneteik lesznek, idegessé, nyugtalanná, ingerlékennyé válnak [21,22].

Az utóbbi évek kutatásai rámutattak arra, hogy az internetfüggőség is a dependenciák közé tartozik, a problémás internethasználók körében funkcionális MR vizsgálatokkal különböző agyi struktúrák eltérése mutatható ki, mely a függőség súlyosságával korrelál [23].

Korábban már vizsgálatuk az internetfüggőség rizikófaktorait és prevalenciáját a bajai Szent Rókus Kórház dolgozói körében. A dolgozók mintegy 4\%-a internetfüggő, mely az egészségügyi dolgozók körében leírt cca. 10\%-os arány alatt van $[1,10]$. Korábbi vizsgálatunk alapján az életkor (<25 év), a családi állapot (nem kapcsolatban élő, ill. gyermektelen dolgozók), a napi 5 órát meghaladó internethasználat, a $<5$ év mun- kaviszony és a munkatípus (egyéb egészségügyi szakdolgozó), valamint a droghasználat és a diabétesz mutatkoztak a kóros internethasználat független rizikótényezőjének [11].

Jelen vizsgálatunk során a depresszió és az alvászavar is szoros összefüggést mutatott az internetfüggőséggel. Az előbb felsorolt tényezők közötti kapcsolat nem teljességgel tisztázott. Lehetséges, hogy a tünetek már az internethasználat előtt is megvoltak, és a hangulat-, illetve alvászavar vezetett a kóros internethasználathoz, esetlegesen ezeket a függőség erősítette fel vagy váltotta ki a pszichiátriai tüneteket $[3,6,9]$. Korábbi vizsgálatunk során a kórelőzményben szereplő hangulatzavar nem mutatott összefüggést a jelenséggel, így felmerül az internetfüggőség kiváltó szerepe a hangulat- és alvászavar létrejöttében jelen eredményeink alapján [11]. A depresszió megelőzése és kezelése kiemelkedően fontos, az Egészségügyi Világszervezet (WHO) szerint az állandó teljesítménykényszer és a munkahelyi túlzott megterhelés miatt 2030-ra a depresszió lesz a vezető betegség, és az ebből adódó halálozás (suicidum) is a vezető halálokok közé fog tartozni [24].

Az internetfüggőség rosszabb életminőséggel is együtt jár vizsgálatunk alapján, ez elsősorban önellátási nehézségekben és fájdalmak gyakoribb kialakulásában mutatkozik meg. Az órákig tartó internetezés mozgásszegény életmódhoz, kényszertartás kialakulásához vezethet, melynek szerepe van a krónikus mozgásszervi fájdalom kialakulásában, mely a munkából való kiesés egyik fő oka [25]. Ráadásul minden egyes számítógép előtt töltött óra 8\%-kal növeli a túlsúly kialakulásának kockázatát, továbbá korábbi munkánkban az internetfüggőség szoros összefüggést mutatott a cukorbetegséggel $[11,26]$. A fent felsorolt tényezők (pszichés + szomatikus) pedig egyértelműen önellátási nehézségekhez vezethetnek. Az életminőség azonban multivariációs analízis során nem bizonyult a kóros internethasználattal szorosan összefüggő tényezőnek, noha korábbi vizsgálatok eredményei ezt mutatták [27,28].

Összegezve, vizsgálatunk felhívja a figyelmet az internetfüggőség előfordulására és mentális következményire kórházi dolgozók körében. Fontos a jelenség szem előtt tartása és felismerése, hiszen a digitalizáció korában az orvostudománynak is új kihívásokkal kell szembenéznie.

Végezetül meg kell említeni, hogy tanulmányunk korlátokkal is bír. Elöször is a minta nem reprezentatív, így következtetéseink sem minden kórházi dolgozóra, sem pedig az egészségügyi szférára általánosságban nem vonatkoznak, csupán a vizsgált populációra. Vizsgálatunk kérdőíves tanulmány, így sem fizikális vizsgálat, sem utánkövetés nem történt, mely az eredményeket befolyásolhatja.

\section{IRODALOMJEGYZÉK}

[1] Pan YC, Chiu YC, Lin YH: Systematic review and metaanalysis of epidemiology of internet addiction. Neurosci Biobehav Rev. 2020;118:612-622.

https://doi.org/10.1016/j.neubiorev.2020.08.013

[2] Zsidó AN, Darnai G, Inhóf O, Perlaki G, Orsi G, Nagy SA, Lábadi $B$, Lénárd $K$, Kovács $N$, Dóczi $T$, Janszky J: Differentiation between young adult Internet addicts, smokers, and healthy controls by the interaction between impulsivity and temporal lobe thickness. J Behav Addict. 
2019;8(1):35-47. https://doi.org/10.1556/2006.8.2019.03

[3] Cheng YS, Tseng PT, Lin PY, Chen TY, Stubbs B, Carvalho AF, Wu CK, Chen YW, Wu MK: Internet Addiction and Its Relationship with Suicidal Behaviors: A Meta-Analysis of Multinational Observational Studies. J Clin Psychiatry. 2018;79(4): 17r11761. https://doi.org/10.4088/JCP.17r11761

[4] Petruzelka B, Vacek J, Gavurova B, Kubak M, Gabrhelik R, Rogalewicz V, Bartak M: Interaction of Socioeconomic Status with Risky Internet Use, Gambling and Substance Use in Adolescents from a Structurally Disadvantaged Region in Central Europe. Int J Environ Res Public Health. 2020;17(13):4803. https://doi.org/10.3390/ijerph17134803

[5] Chia DXY, Ng CWL, Kandasami G, Seow MYL, Choo CC, Chew PKH, Lee C, Zhang MWB: Prevalence of Internet Addiction and Gaming Disorders in Southeast Asia: A MetaAnalysis. Int J Environ Res Public Health. 2020;17(7):2582. https://doi.org/10.3390/ijerph17072582

[6] Pan YC, Chiu YC, Lin YH: Systematic review and metaanalysis of epidemiology of internet addiction. Neurosci Biobehav Rev. 2020;118:612-622. https://doi.org/10.1016/j.neubiorev.2020.08.013

[7] Cheng C, Li AY: Internet addiction prevalence and quality of (real) life: a meta-analysis of 31 nations across seven world regions. Cyberpsychol Behav Soc Netw. 2014; 17(12):755-60. https://doi.org/10.1089/cyber.2014.0317

[8] Chi X, Hong X, Chen X: Profiles and sociodemographic correlates of Internet addiction in early adolescents in southern China. Addict. Behav. 2020 (106): 106385. https://doi.org/10.1016/j.addbeh.2020.106385

[9] Ioannidis K, Hook R, Goudriaan AE, Vlies S, Fineberg NA, Grant JE, Chamberlain SR: Cognitive deficits in problematic internet use: meta-analysis of 40 studies. $\mathrm{Br}$ J Psychiatry. 2019;215(5):639-646. https://doi.org/10.1192/bjp.2019.3

[10] Buneviciene I, Bunevicius A: Prevalence of internet addiction in healthcare professionals: Systematic review and meta-analysis. Int J Soc Psychiatry. 2020: 20764020959093, https://doi.org/10.1177/0020764020959093

[11] Toth G, Kapus K, Hesszenberger D, Pohl M, Kosa G, Kiss J, Pusch G, Fejes E, Tibold A, Feher G: Internet Addiction and Burnout in A Single Hospital: Is There Any Association? Int J Environ Res Public Health. 2021;18(2):E615. https://doi.org/10.3390/ijerph18020615

[12] Demetrovics Z, Szeredi B, Rózsa S: The three-factor model of Internet addiction: the development of the Problematic Internet Use Questionnaire. Behav Res Methods. 2008;40(2):563-74. https://doi.org/10.3758/BRM.40.2.563

[13] Kovács M, Makkos A, Pintér D, Juhász A, Darnai G, Karádi K, Janszky J, Kovács N: Screening for Problematic Internet Use May Help Identify Impulse Control Disorders in Parkinson's Disease. Behav Neurol. 2019;2019:4925015, https://doi.org/10.1155/2019/4925015

[14] Demetrovics Z, Szeredi B, Nyikos E: A Problémás Inter- nethasználat Kérdőív bemutatása. Psychiatria Hungarica, 2004;19(2): 141-160.

[15] Beck AT, Ward CH, Mendelson M, et al.: An inventory for measuring depression. Arch Gen Psychiatry. 1961(4): 561-571. https://doi.org/10.1001/archpsyc.1961.01710120031004

[16] Rózsa S, Szádóczky E, Füredi J: A Beck Depressziós Kérdőív rövidített változatának jellemzői hazai mintán. Psych Hung, 2001(4): 384-402.

[17] Soldatos CR, Dikeos DG, Paparrigopoulos TJ: Athens Insomnia Scale: validation of an instrument based on ICD-10 criteria. J Psychosom Res. 2000;48(6):555-60. https://doi.org/10.1016/S0022-3999(00)00095-7

[18] Fusz K, Faludi B, Pusztai D, Sebők N, Oláh A: Insomnia és elalvást segítő szokások felmérése felnőttek körében. Orv Hetil. 2016;157(49):1955-1959. https://doi.org/10.1556/650.2016.30593

[19] EuroQol Group. EuroQol--a new facility for the measurement of health-related quality of life. Health Policy. 1990;16(3):199-208. https://doi.org/10.1016/0168-8510(90)90421-9

[20] Fábián G: Alkalmazott kutatás módszertan (2014). Debreceni Egyetem Egészségügyi Kar

[21] https://www.hazipatika.com/betegsegek_a_z/internetfuggoseg/821. Megtekintve: 2021.03.05.

[22] Galán A: Az internetfüggőség kialakulása és prevalenciája. Metszetek 2014(1-2): 316-327.

[23] Qin K, Zhang F, Chen T, Li L, Li W, Suo X, Lei D, Kemp GJ, Gong Q: Shared gray matter alterations in individuals with diverse behavioral addictions: A voxel-wise metaanalysis. J Behav Addict. 2020;9(1):1-14. https://doi.org/10.1556/2006.2020.00006

[24] Malhi GS, Mann JJ: Lancet. 2018;392: 2299-2312. https://doi.org/10.1016/S0140-6736(18)31948-2

[25] Yang G, Cao J, Li Y, Cheng P, Liu B, Hao Z, Yao H, Shi D, Peng L, Guo L, Ren Z: Association Between Internet Addiction and the Risk of Musculoskeletal Pain in Chinese College Freshmen - A Cross-Sectional Study. Front Psychol. 2019;10:1959. https://doi.org/10.3389/fpsyg.2019.01959

[26] Aghasi M, Matinfar A, Golzarand M, Salari-Moghaddam A, Ebrahimpour-Koujan S: Internet Use in Relation to Overweight and Obesity: A Systematic Review and MetaAnalysis of Cross-Sectional Studies. Adv Nutr. 2020; 11(2):349-356. https://doi.org/10.1093/advances/nmz073

[27] Cam HH, Ustuner Top F: Prevalence and Risk Factors of Problematic Internet Use and Its Relationships to the Self-Esteem and Health-Related Quality of Life: Data from a High-School Survey in Giresun Province, Turkey. J Addict Nurs. 2020;31(4):253-260. https://doi.org/10.1097/JAN.0000000000000365

[28] Xu DD, Lok KI, Liu HZ, Cao XL, An FR, Hall BJ, Ungvari GS, Lei SM, Xiang YT: Internet addiction among adolescents in Macau and mainland China: prevalence, demographics and quality of life. Sci Rep. 2020;10(1):16222. https://doi.org/10.1038/s41598-020-73023-1 


\section{A SZERZŐK BEMUTATÁSA}

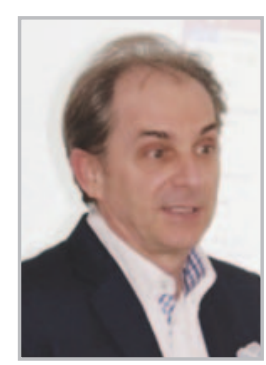

Dr. Tóth Gábor a Pécsi Orvostudományi Egyetemen végzett általános orvosként 1989-ben. 1993-ben urológiából, 2000-ben pedig andrológiából szerzett szakvizsgát. 1989 októbere óta dolgo-

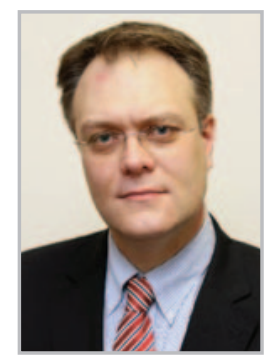

Dr. Tibold Antal 2003-ban diplomázott a Pécsi Tudományegyetem Általános Orvostudományi Karán. A végzés után a Kar Orvosi Népegészségtani Intézetében helyezkedett el. 2004-ben az Intézeten belül megalakuló Foglalkozás- és Munkaegészségtani Tanszéki Csoport munkatársa lett, jelenleg tanszékvezető. 2009-től a PTE Klinikai

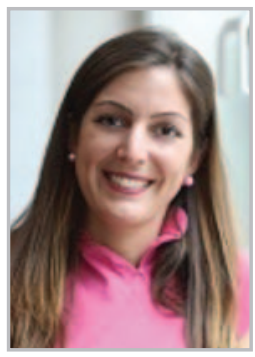

Fejes Éva 2010-ben végzett közgazdászként a Pécsi Tudományegyetem Közgazdaságtudományi Karának pénzügy és számvitel alapképzési szakán, majd 2013-ban pénzügy mesterképzési szakon okleveles közgazdászként. 2017-ben a Pécsi Tudományegyetem Egészségtudományi Karán okleveles egészségügyi menedzser végzettséget is szerzett. Emellett mérlegképes könyvelői, valamint gaz-

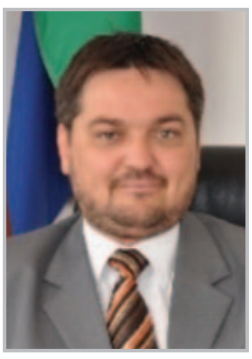

Kapus Krisztián, pedagógus, katolikus hittanár, teológus. A Magyar Közút Nonprofit Zrt. felnőttképzési szakmai vezetője. Felsőfokú tanulmányait a Juhász Gyula Főiskolán, a József Attila Tudományegyetemen, a Szegedi Hittudományi Főiskolán, a Pannon Egyetemen, az Eötvös Lóránd Tudományegyetemen, a Pázmány Péter Katolikus

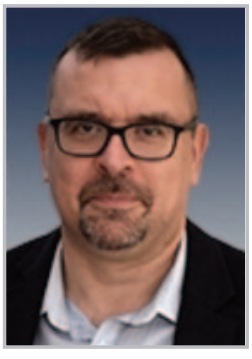

Dr. Fehér Gergely neurológus, vaszkuláris neurológus (agyérbeteg-specialista). Orvosi diplomáját 2003-ban szerezte, neurológiából 2011-ben tett szakvizsgát. PhD fokozatát 2009-ben, habilitációs fokozatát 2017-ben nyerte el. Szakmai és tudományos eredményei alapján beválasztásra került „Az orvostudomány jövőformálói - TOP 25 feltörekvő tehetség" című kiadványba 2014-ben, valamint 2020- zik a Bajai Szent Rókus Kórházban, amelynek főigazgatója 2007 óta. Orvos-közgazdászi és európai projektmenedzser képesítéssel is rendelkezik. 2020 óta Pécsi Tudomány Egyetem PhD hallgatója. A Magyar Kórházszövetség elnökségi tagja, a Bács Kiskun megyei Vöröskereszt elnöke.

Központjában a Foglalkozás-egészségügyi és Munkahigiénés Központ igazgató főorvosa. A Magyar Üzemorvosok Tudományos Társaságának vezetőségi tagja, az Egészségügyi Szakmai Kollégium Foglalkozás orvostan Tagozatának titkára, alapítója a Pécsi Tudományegyetemen a Munkatudományi és Foglalkozás-egészségügyi Kiválósági Központ és Kutatócsoportnak, valamint a Pécsi Tudományegyetem Munkatudományi és Foglalkozás-egészségügyi Tehetség Centrumának.

dasági informatikusi képesítéssel is rendelkezik és részt vett pályázatíró, projektmenedzser képzésen is. Jelenleg a Pécsi Tudományegyetem Általános Orvostudományi Kara Klinikai Orvostudományok Doktori Iskolájának PhD hallgatója, kutatási témája a munkaképesség csökkenés két tényezőjének, az egészségügyi dolgozók kiégésének és a fejfájásnak a komplex vizsgálata. 2007 óta a Komlói Egészségcentrum és BUESZ Egészségügyi Központban dolgozik, 2012 óta gazdasági igazgatói pozícióban.

Egyetemen, a Pécsi Tudományegyetemen, a Szegedi Tudományegyetemen, a Gál Ferenc Főiskolán és a Nemzeti Közszolgálati Egyetemen végezte. Kutatási területe a magyar ifjúság helyzete, szokásaik, attitűdjeik. Oktatóként tanított a SZTE Juhász Gyula Pedagógiai Karán. Jelenleg a PTE Klinikai Idegtudományi Doktori Iskolájának PhD hallgatója. Kutatási területe az internetfüggőség és annak komplex háttere, következményei a középiskolás diákok, valamint a pedagógusok körében.

ban Magyar Arany Érdemkereszt kitüntetésben részesült. Korábban osztályvezető főorvosi pozíciót töltött be, jelenleg a járóbeteg-ellátás mellett a kutatói és oktatói feladatait végzi. Az egyetemi oktatásban a Pécsi Tudományegyetem Klinikai Idegtudományok Doktori Iskola témavezetője, fő kutatási témája az agyérbetegségek, a krónikus fájdalom szindrómák és a komplex foglalkozás-egészségügyi felmérések. A fentiek mellett a Magyar Gnatológiai Társaság vezetőségi tagja, valamint több nemzetközi folyóiratban szerkesztőbizottsági tag. 